\title{
Spatial analysis of risk areas for the development of tuberculosis and treatment outcomes
}

\author{
Análise espacial de área de risco para tuberculose e os desfechos no tratamento \\ Análisis espacial de áreas de riesgo para desarrollo de la tuberculosis y desfechos del tratamiento
}

Hamilton Leandro Pinto de Andrade' ORCID: 0000-0003-4576-0655

Antônio Carlos Vieira Ramos' ORCID: 0000-0002-7862-1355

Juliane de Almeida Crispim' ORCID: 0000-0003-4642-9075

Marcelino Santos Neto" ORCID: 0000-0002-6105-1886

Luiz Henrique Arroyo' ORCID: 0000-0003-3302-0502

Ricardo Alexandre Arcêncio' ORCID: 0000-0003-4792-8714

'Universidade de São Paulo. Ribeirão Preto, São Paulo, Brazil. "Universidade Federal do Maranhão. Imperatriz, Maranhão, Brazil.

How to cite this article: Andrade HLP, Ramos ACV, Crispim JA, Santos Neto M, Arroyo LH, Arcêncio RA. Spatial analysis of risk areas for the development of tuberculosis and treatment outcomes

Rev Bras Enferm. 2021;74(2):e20200564. https://doi.org/10.1590/0034-7167-2020-0564

Corresponding author: Hamilton Leandro Pinto de Andrade E-mail: hamilandrade@hotmail.com

EDITOR IN CHIEF: Antonio José de Almeida Filho ASSOCIATE EDITOR: Mitzy Reichembach

\begin{abstract}
Objectives: to identify risk clusters for the occurrence of tuberculosis and its treatment outcomes. Methods: ecological study, in a city in Maranhão, using data from the Notifiable Diseases Information System. Point density analysis and isotonic scanning techniques were used to identify areas with the highest occurrence of treatment outcomes and identify risk areas for possible tuberculosis cases. Results: most tuberculosis cases occurred in the male, adult, brown-skinned population. Also, most of the reported cases were classified as pulmonary and as new cases that progressed to a cure. The areas with the highest density of cure, death and abandonment are located in the central region of the city. Conclusions: the central region of the urban area of the city, with high demographic density and poor sanitary and socioeconomic conditions, presented a greater cluster of tuberculosis cases. Descriptors: Tuberculosis; Ecological Parameter; Spatial Analysis; Risk Factors; Nursing.
\end{abstract}

\section{RESUMO}

Objetivos: identificar aglomerados de risco para ocorrência da tuberculose e desfechos no tratamento. Métodos: estudo ecológico, realizado em município maranhense, usando dados do Sistema de Informação de Agravos de Notificação. Utilizou-se técnica de análise de densidade de pontos e de varredura isotônica, para identificação das áreas de maior ocorrência dos desfechos no tratamento e identificação das áreas de risco para os casos de tuberculose. Resultados: a maioria dos casos de tuberculose ocorreu em pessoas do sexo masculino, adultos, da raça parda. Também, a maior parte dos casos notificados classificouse como pulmonar e se referiu a casos novos, progredindo para a cura. As áreas com maior densidade de cura, óbito e abandono estão localizadas na região central do município. Conclusões: a região central da área urbana da cidade, com alta densidade demográfica e precárias condições sanitárias e socioeconômicas, apresentou maior aglomerado de casos de tuberculose.

Descritores: Tuberculose; Estudos Ecológicos; Análise Espacial; Área de Risco; Enfermagem.

\section{RESUMEN}

Objetivos: identificar aglomerados de riesgo para ocurrencia de tuberculosis y desfechos en el tratamiento. Métodos: estudio ecológico, realizado en Maranhão, usando datos del Sistema de Información de Agravios de Notificación. Utilizó técnica de análisis de densidad de puntos y de barredura isotónica, para identificación de áreas de mayor ocurrencia de los desfechos en el tratamiento e identificación de áreas de riesgo para los casos de tuberculosis. Resultados: mayoría de los casos de tuberculosis ocurrió en personas del sexo masculino, adultos, de la raza parda. También, la mayor parte de los casos notificados se clasificó como pulmonar y se refirió a casos nuevos, progresando hacia la cura. Áreas con mayor densidad de cura, óbito y abandono están ubicadas en la región central del municipio. Conclusiones: la región central del área urbana de la ciudad, con alta densidad demográfica y precarias condiciones sanitarias y socioeconómicas, presentó mayor aglomerado de casos de tuberculosis. Descriptores: Tuberculosis; Estudios Ecológicos; Análisis Espacial; Área de Riesgo; Enfermería. 


\section{INTRODUCTION}

The spatial distribution of endemic diseases, including tuberculosis, is currently the object of studies of geographic epidemiology. Researches that link these diseases to geographic space has been of great value to the scientific community, since the dynamics of these spaces, as well as the changes resulting from human occupation, have an impact on the occurrence, incidence and/or maintenance of diseases, as well as on the effectiveness or failure of public health policies implemented ${ }^{(1-5)}$.

The use of technologies based on geographic information systems can contribute to the understanding of the distribution dynamics of disease cases, including tuberculosis, since it can facilitate the identification of areas or places at risk ${ }^{(4)}$. These technologies can also be an important tool for the management and planning of health policies or programs, supporting strategies for tuberculosis control and prevention ${ }^{(5)}$.

Thus, geographic information technologies are able to assist Health Surveillance Services. This national policy is responsible for actions of surveillance, prevention and control of communicable diseases, as well as for the analysis of the health situation of the Brazilian population ${ }^{(6)}$.

In the field of nursing, researches involving health surveillance are of great relevance, considering that, during academic training, nurses are prepared to work in epidemiological research and for being at the forefront of health care ${ }^{(7)}$. These professionals can actively participate in the population's health-disease process, acting in direct contact with users, the community and the multidisciplinary team, in the conduct of public health actions ${ }^{(8)}$.

In addition, it is emphasized that the use of these technologies can both promote better control of tuberculosis, assisting in the search or fulfillment of goals, as well as facilitating the observation of the commitment of the federated entities in relation to tuberculosis, depending on the time. This should be carried out by state and city administrative agents in the management of public resources, and by the Union ${ }^{(9)}$.

Regarding the global epidemiological panorama, tuberculosis is still seen as a serious public health problem in the world, being strongly related to poverty and poor income distribution ${ }^{(10)}$. It has a high mortality rate, being one of the biggest causes of morbidity and mortality in the world ${ }^{(11)}$. It is essentially urban, associated with social determinants of health and the population and/or individual living conditions, which contributes to demonstrate the complex reality linked to the disease $\mathrm{e}^{(12-13)}$.

In 2018, Brazil had an incidence coefficient of 34.8 cases per hundred thousand inhabitants. In the Northeast Region, with 33.1 cases per 100 thousand inhabitants, being classified as one of the Brazilian regions with the highest incidence coefficient for this disease. In the state of Maranhão, the coefficient of incidence of cases was approximately 30.3 cases per hundred thousand inhabitants: in the capital, São Luís, it reached 62.3 per hundred thousand inhabitants ${ }^{(14)}$; in the city of Imperatriz, according to data from the State Health Plan, in the period from 2016 to 2019, it was of 10.2 cases per hundred thousand inhabitants ${ }^{(15)}$.

The city of Imperatriz can be considered one of those that integrate scenario 1 of the classification of the National Plan for the End of Tuberculosis as a Public Health Problem. The municipality reported an average of $25 \%$ to $27.8 \%$ of new tuberculosis cases, in addition to having demonstrated that it is an endemic disease concentrated in vulnerable populations, justifying the development of studies to understand the spatial distribution of cases ${ }^{(16)}$.

In addition, it is believed that the dissemination of information obtained in this research should contribute to the actions of tuberculosis control in that municipality by public agents, subsidizing measures for socioeconomic and sanitary improvements of the population. It should also serve as an instrument of articulation with the Family Health Strategy teams, guiding their actions for health promotion in the municipality.

In this context, the following question is necessary: What are the spatial clusters at risk for the development of tuberculosis and what are the treatment outcomes in a municipality in Northeast Brazil?

\section{OBJECTIVES}

To identify the spatial clusters at risk for the occurrence of tuberculosis and the treatment outcomes in a Brazilian municipality.

\section{METHODS}

\section{Ethical aspects}

The study was approved by the Research Ethics Committee of the Ribeirão Preto School of Nursing, University of São Paulo, following the ethical recommendations of the National Health Council, according to Resolution 466/2012.

\section{Study design, period and location}

This is an ecological study conducted in 2019, in the city of Imperatriz. According to data from the Brazilian Institute of Geography and Statistics (IBGE) for the year 2019, Imperatriz has an estimated population of 258.016 people, with a demographic density of 180.79 per $\mathrm{km}^{2}$ and a territorial area of $1.368 .988 \mathrm{~km}^{(16)}$. Regarding socioeconomic indicators, the city has an illiteracy rate of $9.7 \%$, life expectancy at birth of 73.2 years, Municipal Human Development Index (MHDI) of 0.73 , social exclusion index of 0.6 , poverty incidence of $55.28 \%$ and Gini coefficient of 0.46 . Regarding basic sanitation, $23 \%$ of the city has a sewage system; and $86 \%$ a clear water supply ${ }^{(17)}$.

EQUATOR guidelines were followed, using the Strengthening the Reporting of Observational Studies in Epidemiology (STROBE) instrument.

\section{Population or sample, inclusion and exclusion criteria}

Tuberculosis cases obtained in the Notifiable Diseases Information System (Sinan), with dates of diagnostic from 2013 to 2018 were considered. The variables selected were: race, sex, age group, form of tuberculosis, start of treatment, outcome and home address.

Secondary data were collected at the Health Surveillance Service of the Imperatriz Regional Health Management Unit, of the Maranhão state government, in February 2019. In the data collection process, the information was tabulated in Microsoft ${ }^{\circ}$ Office Excel 2013 spreadsheets, going through the database validation process and removing duplicate notifications. Cases 
in the "treatment outcomes" field that were filled in as "change of diagnosis" were excluded from the analyses, as they did not correspond to tuberculosis cases ${ }^{(18)}$. The ecological analysis units of the study were the 218 Imperatriz urban census sectors.

\section{Analysis of results and statistics}

Descriptive analysis of the variables of the cases was performed, with the calculation of absolute and relative frequencies and rates, according to subgroups of each variable. In the calculation of the rates, for the variables "age group" and "sex", the denominator was the municipal population for each subgroup, that is, population stratified according to the age groups (under 15 years old; 15 to 59 years old; and over 60 years old), and men and women, for the variable "sex". For the variables "form of tuberculosis", "cause of entry" and "outcome of treatment", the coefficients were not calculated, as there is exclusively information about the total population, and not about these categories. For the calculation, the municipal population of Imperatriz in 2010 (year corresponding to the last Brazilian census) and the number of years of study (6 years) were considered, with the multiplication factor being one hundred thousand (inhabitants).

Tuberculosis cases were geocoded based on the geographic coordinates of latitude and longitude of the residential addresses of each case. The free access software Google Maps" was used to identify geographic coordinates; and the ArcGis 10.6 software, with the construction of a file containing the geographical coordinates of each case in SIRGAS2000 projection for georeferencing. Cases whose addresses were located in a rural area, without an address and/or were incomplete were excluded from this stage. Thus, of the 434 total cases, 413 remained after applying the exclusion criteria.

To identify the areas with the highest occurrence of the outcomes "death", "cure" and "abandonment" of tuberculosis cases, the technique of point density analysis, defined as the Kernel density estimator, was used. It is very useful to provide an overview of the distribution of sample points, as well as an indication of the occurrence of clusters, suggesting spatial dependence ${ }^{(19-21)}$. It is important to highlight that the Kernel estimator has, as a basic parameter, the radius of influence ${ }^{(20-21)}$ which defines the neighborhood of the point to be interpolated and controls the smoothness of the surface generated ${ }^{(20-21)}$. Small radii of influence can generate the representation of discontinuous and oscillating areas (surfaces); at the same time, if they are too large, the surface can become very smooth and wide, not representing the event of interest in a real way ${ }^{(20)}$.

In this sense, to avoid the problem with the use of very small or large rays, we used the tool provided by the ArcGis 10.6 software, called Incremental Spatial Autocorrelation (ISA), which, by measuring the spatial autocorrelation of distances, defines the best conformation of the spatial grouping (risk areas), indicating the best influence radius ${ }^{(21-22)}$.

Considering the radius of influence of one thousand meters defined by the ISA tool, thematic maps of the density distribution of the outcomes "cure", "death" and "abandonment", according to home address, were generated in the ArcGis 10.6 software.

To identify the risk areas related to the cases of the disease, the technique of isotonic scanning statistics, or scan statistics, proposed by Kulldorff and Nagarwalla in $1995^{(23-25)}$ was used. This analysis technique allows the gradual visualization of the spatial risk intensity within the cluster ${ }^{(26)}$. Considering the maximum size of the cluster equal to $50 \%$ of the exposed population, the spatial statistics of isotonic scanning were performed using SaTScan ${ }^{\mathrm{TM}} 9.6$ software.

In the next section, the results from the statistical methods used will be presented, as well as the descriptive analysis of the case variables.

\section{RESULTS}

Most cases of tuberculosis were in males $(260 ; 62 \%)$, aged 15 to 59 years $(328 ; 78 \%)$ and of brown skin color $(263 ; 62.6 \%)$. There were four cases of tuberculosis in children under 2 years old, two cases in 2014, one in 2015 and one in 2016.

Regarding the form of tuberculosis, most were classified as pulmonary $(368 ; 87.6 \%)$, as well as most of the cases reported were new cases $(374 ; 89.0 \%)$ that progressed to a cure $(342$; 81.4\%) (Table 1).

Regarding treatment outcomes for cure, new cases and abandonment, Imperatriz presented rates of $81.4 \%, 89.0 \%$ and $1.6 \%$, respectively. Concerning the spatial distribution of tuberculosis cases, 21 cases out of 434 were disregarded due to incomplete addresses, with 9 cases without a house number (2\%) and 5 cases with a blank address (1.1\%), in addition to 7 cases (1.6\%) classified as "change in diagnosis", totaling 413 georeferenced cases (95.1\%).

Table 1 - Sociodemographic and clinical-epidemiological characteristics of tuberculosis cases and respective rates per hundred thousand inhabitants in the period 2013-2018, Imperatriz, Maranhão, Brazil, 2020

\begin{tabular}{|c|c|c|}
\hline Variable & n (\%) & $\begin{array}{c}\text { Rate } \\
\text { (per hundred } \\
\text { thousand inhabitants) }\end{array}$ \\
\hline \multicolumn{3}{|l|}{ Gender } \\
\hline Male & 256 (61.9) & 35.4 \\
\hline Female & $157(38.0)$ & 20.1 \\
\hline \multicolumn{3}{|l|}{ Skin color } \\
\hline Brown & $259(62.7)$ & 22.9 \\
\hline white & $94(22.8)$ & 42.7 \\
\hline Black & $50(12.1)$ & 60.4 \\
\hline Yellow & $10(2.3)$ & 18.5 \\
\hline \multicolumn{3}{|l|}{ Age group, years } \\
\hline$<15$ & $17(4.0)$ & 4.23 \\
\hline $15-59$ & $324(78.4)$ & 33.3 \\
\hline$>60$ & $72(17.4)$ & 58.3 \\
\hline \multicolumn{3}{|l|}{ Tuberculosis form } \\
\hline Pulmonary & $363(87.8)$ & * \\
\hline Extrapulmonary & $40(9.7)$ & * \\
\hline Pulmonary and extrapulmonary & $10(2.4)$ & * \\
\hline \multicolumn{3}{|l|}{ Type of entry } \\
\hline New casa & $370(89.6)$ & * \\
\hline Relapse & $22(5.3)$ & * \\
\hline Re-entry & $5(1.1)$ & * \\
\hline Transfer & $16(3.9)$ & * \\
\hline \multicolumn{3}{|l|}{ Treatment outcome } \\
\hline Cure & $342(81.4)$ & $*$ \\
\hline Abandonment & $7(1.6)$ & * \\
\hline Death from tuberculosis & $1(0.2)$ & * \\
\hline Death from other causes & $13(3.0)$ & * \\
\hline TB drug resistant & $4(0.9)$ & * \\
\hline Primary Abandonment & $1(0.2)$ & * \\
\hline Not evaluated & 45 (10.6) & * \\
\hline
\end{tabular}

Note: *Rates have not been calculated. 


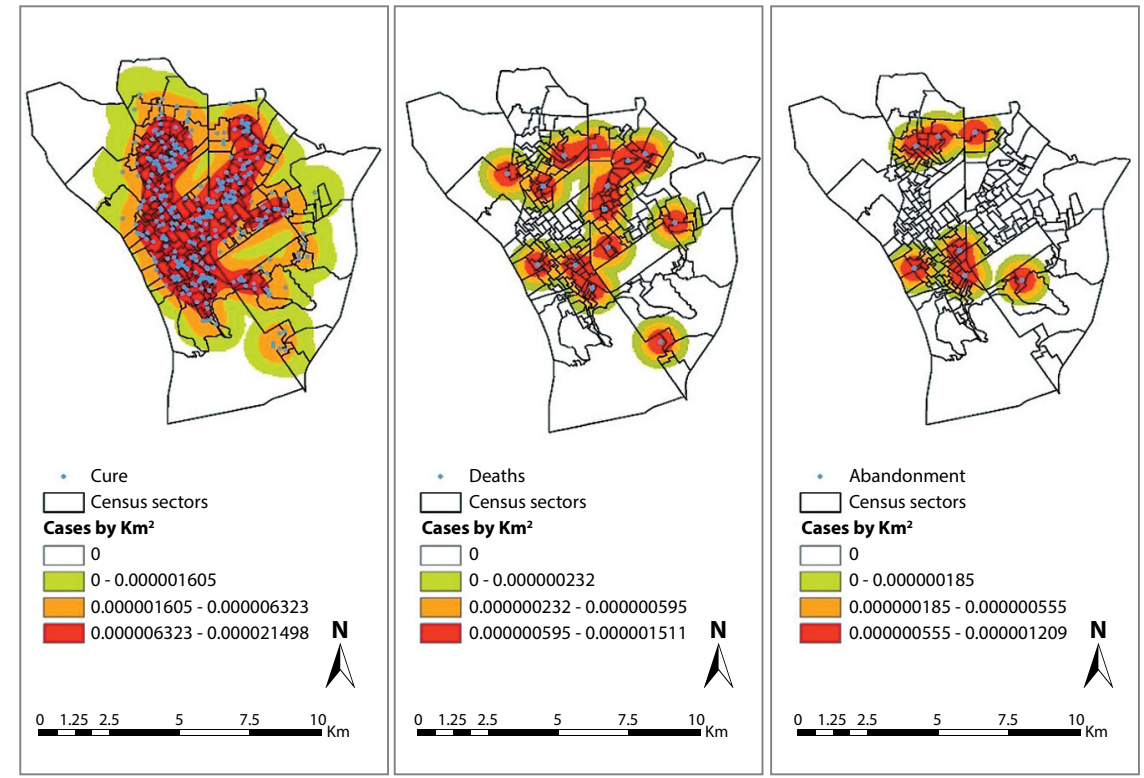

Figure 1 - Areas with the highest density of cure, death and abandonment outcomes due to tuberculosis in the period 2013-2018, Imperatriz, Maranhão, Brazil, 2020
Using isotonic scanning statistics, it was possible to identify a cluster of statistically significant risk for cases of the disease, with a $p$-value of 0.0013 , relative spatial risk of 1.41 (confidence interval 1.14-1.73), with 129 cases, incidence rate of 38.5 per hundred thousand inhabitants and log likelihood of 14.1. Seven Steps in Risk Function were also identified, whose relative spatial risk ranged from 8.52 (in step 1) to 1.16 (in step 7).

The spatial risk cluster comprised the neighborhoods Boca da Mata, Bacuri, Cafeteira, Vila Lobão, Parque Alvorada II, Beira Rio, and Nova Imperatriz. The Health Districts that provide assistance to these neighborhoods are: Cafeteira, Bacuri and Santa Rita (Figure 2). Distant from the noble areas of the city, whose infrastructure is well favored, these neighborhoods are characterized by precarious conditions of infrastructure and basic sanitation.

It can be observed, then, that the $\mathbf{N}$

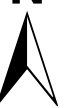

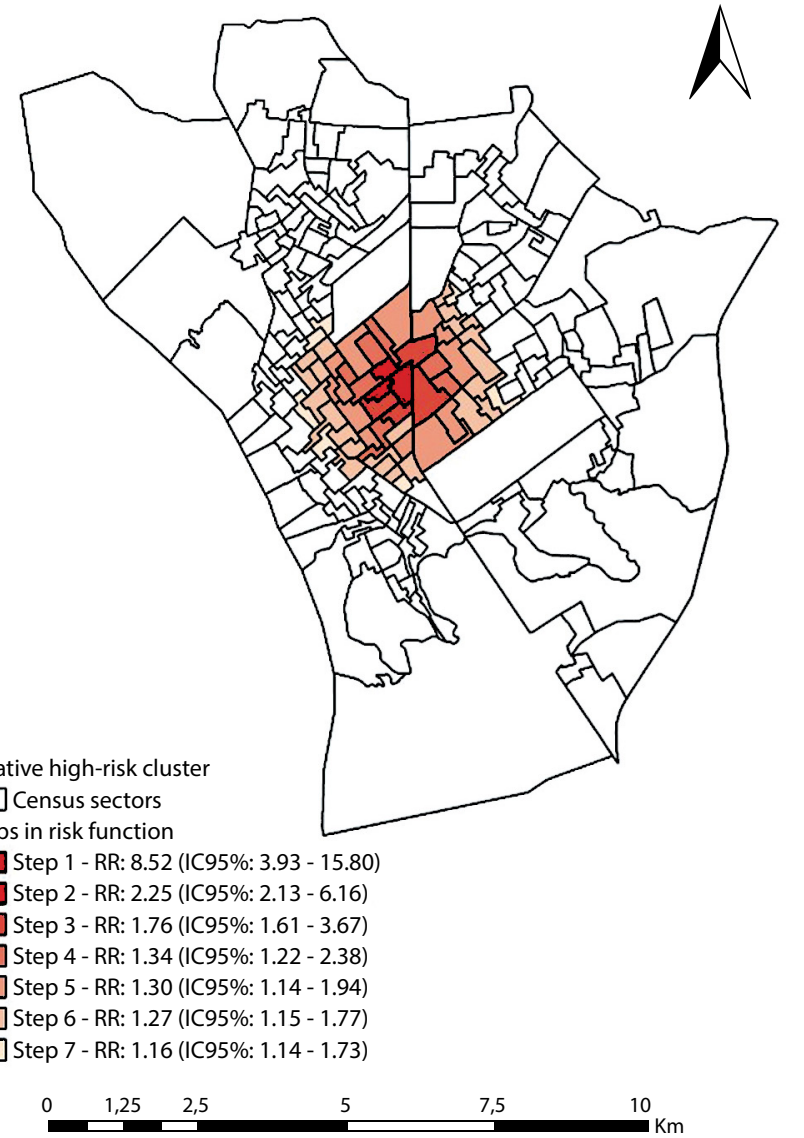

Note: $R R$ - Relative Risk; $95 \% \mathrm{Cl}-95 \%$ confidence interval.

Figure 2 - Spatial clusters of high risk for tuberculosis in the period 20132018, Imperatriz, Maranhão, Brazil, 2020

Through the Kernel density estimation, it was possible to identify that the areas with the highest density of cure, death and abandonment were located in the central region of the municipality (Figure 1). neighborhoods, which make up the spatial cluster of risk mentioned above, are located far from the areas considered noble of the city - whose infrastructure is well favored - and, therefore, present precarious conditions of infrastructure and basic sanitation.

\section{DISCUSSION}

Of the cases surveyed, $97 \%$ were geo-referenced, which is satisfactory, since this proportion indicates good completeness of coverage and quality of the information recorded in SINAN regarding the addresses of the cases notified in the health information systems ${ }^{(27) .}$ Areas of low risk for the occurrence of tuberculosis need to be analyzed with due parsimony, since they may be the result of underreporting of the cases of the disease, a phenomenon still common in Brazil and which requires investment in surveillance ${ }^{(27)}$.

According to gender, the male predominance follows the worldwide distribution of tuberculosis cases. Regarding the treatment outcomes, the percentage of the "cure" outcome in Imperatriz is higher than the national one, while the "abandonment" and "new cases" outcomes had lower percentages, also compared to national results ${ }^{(14)}$.

A possible explanation for the treatment outcomes discussed above is found in the effectiveness of services to combat tuberculosis by municipal health managers. However, this statement needs further studies to assess the effectiveness and impact of the municipality's health actions.

Still, the area that has the largest spatial agglomeration of urban risk has had, in the last decades, a disorderly population growth, characterized by precarious housing and sanitary conditions. This area still has low family income, low purchasing power, low education, insufficient medical resources, a high number of inhabitants per household (intra-domiciliary transmission) and a large cluster of homes with poor ventilation and light, factors that can increase the risks for tuberculosis transmission ${ }^{(4-5)}$. 
Such determinants are called social determinants of health and comprise socioeconomic, cultural, ethnic-racial, psychological and behavioral factors, which influence the occurrence of health problems and their risk factors in the population ${ }^{(28-31) .}$

Supporting the approach to social determinants means understanding the value that health has for society and admitting that it depends on socioeconomic and health actions, which often have no direct relationship with the health sector. Without the implementation of actions regarding social determinants, the sustainable development objectives (SDOs), directly linked to the health area, will not be met ${ }^{(13)}$.

From this perspective, public policies have a central importance - for example, transporting and housing policies, at the local level; fiscal, environmental, educational and social policies at the national level; and financial, commercial and agricultural policies at the global level ${ }^{(13)}$.

Furthermore, it is also important to think about basic sanitation not only as a prevention of endemic diseases, but also as health promotion. Basic sanitation must take place in order to prevent and control diseases and provide well-being for the population. Considering this logic, health is the result of conditions of nutrition, housing, education, income, environment, work, transportation, employment, leisure, freedom and access to health services ${ }^{(12)}$.

On the other hand, recent studies claim that the increase in the poorest populations in community areas, living under unsanitary conditions and overcrowding in households with sanitary deficiencies, facilitates the proliferation of tuberculosis worldwide ${ }^{(4-5,14)}$.These populations, said to be vulnerable, are more susceptible to tuberculosis, as well as those living with HIV/AIDS, diabetes, or other chronic comorbidities; populations deprived of their liberty; people residing in border regions; indigenous populations; people subjected to social and economic deprivation; among others ${ }^{(31-33)}$.

Health, therefore, is not just the absence of disease, since it encompasses several aspects interrelated to the individual/society and requires the elaboration, planning and implementation of intersectoral actions, focusing on the needs of the population.

\section{Study Limitations}

The limitations of this research refer to the fact that the study presents a succinct mapping of areas at risk for cases of tuberculosis and treatment outcomes. In addition, there is the possibility of underreporting in areas considered to be of low risk and errors in the information related to the addresses of the cases, since the information collected was through secondary data ${ }^{(27)}$.

However, the spatial scan statistics contributed to expose both the tuberculosis scenario in Imperatriz and the presence of geographic areas of the municipality that are more susceptible to illness and lack specific actions to control the disease ${ }^{(27)}$.

\section{Contributions to the area of Nursing, Health or Public Policy}

For a disease of a social nature, such as tuberculosis, it is of fundamental importance that there is a health education capable of empowering sick citizens, so that they can achieve improvements in their quality of life ${ }^{(32)}$.

Educational practices, which must be implemented primarily by teams in health services and health strategies, must be developed at the individual and collective levels, promoting healing and rehabilitation, with the user and the community as allies and protagonists of the therapeutic process and mobilizations for the expanded right to health ${ }^{(22)}$.

The proposal to identify the probable clusters of risk for tuberculosis strengthens the fight against this disease and the achievement of the goals established in the National Plan for the End of Tuberculosis as a Public Health Problem. It subsidizes the strengthening of health services and care and prevention actions among individuals, based on the early detection of cases in places that are possible sources of infection ${ }^{(31)}$.

Although this study does not aim to evaluate the access to health services, it is important to highlight that the heterogeneous distribution of risks for tuberculosis could be influenced both by the location of these services and by the quality with which they are offered to populations ${ }^{(27)}$.

\section{CONCLUSIONS}

The central region of the urban area of the city showed a greater cluster of tuberculosis cases. It is an area with high demographic density and poor sanitary and socioeconomic conditions. Cases were recorded throughout the urban area of the city, but the largest number of cases occurred in the central urban region of the municipality, with emphasis on the "cure" outcome.

Other studies with analytical designs that are able to verify, with greater precision, possible associations between the areas of greatest risk for tuberculosis and the treatment outcomes are indispensable, and relating those results with social vulnerability is very important, since this research did not establish such a relationship, since it maps only of areas at risk for tuberculosis, composing an exploratory study. However, with regard to social and health aspects, it is believed that this work can contribute to the population of Imperatriz, assisting public managers in planning, developing and implementing measures to combat, control and prevent future cases of tuberculosis.

Other, more robust studies should be conducted, using other analyzes and more advanced statistical models, aiming, for example, to analyze the spatial and spatial-temporal relationship of tuberculosis cases in the municipality.

\section{FUNDING}

National Council of Science and Technology (CNPq): PhD scholarship.

\section{REFERENCES}

1. Leal BN, Mesquita CR, Nogueira LM, Rodrigues IL, Oliveira LF. Análise espacial em tuberculose e a rede de atenção primária em saúde. Rev Bras Enferm. 2019;72(5):1-6. https://doi.org/10.1590/0034-7167-2017-0897 
2. Yamamura M, Santos Neto M, Chiaravalloti Neto F, Arroyo LH, Ramos AC, Queiroz AR, et al. Areas with evidence of equity and their progress on mortality from tuberculosis in an endemic municipality of southeast Brazil. Infect Dis Poverty. 2017;6(1):134. https://doi.org/10.1186/ s40249-017-0348-5

3. Arroyo LH, Arcoverde MA, Alves JD, Fuentealba-Torres M, Cartagena-Ramos D, Scholze AR, et al. Spatial analysis of cases of tuberculosis with mental disorders in São Paulo. Rev Bras Enferm. 2019;72(3):1-9. https://doi.org/10.1590/0034-7167-2017-0949

4. Wang X, Yin S, Li Y, Wang W, Du M, Guo W, et al. Spatiotemporal epidemiology of, and factors associated with, the tuberculosis prevalence in northern China, 2010-2014. BMC Infec Dis. 2019;19:365. https://doi.org/10.1186/s12879-019-3910-x

5. Mao Q, Zeng C, Zheng D, Yang Y. Analysis on spatial-temporal distribution characteristics of smear positive pulmonary tuberculosis in China, 2004-2015. Int J Infect Dis. 2019;S36S44. https://doi.org/10.1016/j.jij.2019.02.038

6. Ministério da Saúde (BR). Secretaria de Vigilância em Saúde. Programa Nacional de Vigilância em Saúde [Internet]. Brasília, DF: Ministério da Saúde. 2017 [cited 2019 Oct 4]. Available from: http://www.saude.gov.br/vigilancia-em-saude/sobre-vigilancia-em-saude

7. Allgayer MF. Tuberculose: ações assistências e de vigilância em unidades penitenciárias do Rio Grande do Sul (RS). Santa Cruz do Sul: Universidade de Santa Cruz do Sul, 2015.

8. Meirelles RJ, Palha PF. Directly observed treatment for tuberculosis in the state of São Paulo. Rev Bras Enferm. 2018;72(5):1167-72. https:// doi.org/10.1590/0034-7167-2017-0279

9. Allgaye MF, Ely KZ, Freitas GH, Valim AR, Gonzales RI, Krug SB, et al. Tuberculosis: health care and surveillance in prisons. Rev Bras Enferm. 2019;72(5):1304-10. https://doi.org/10.1590/0034-7167-2018-0260

10. Costa MM, Costa ES, Vilaça DH, Tavares AV, Menezes HL, Brito LM. Pulmonary tuberculosis: epidemiological profile of Sertão Pernambucano, Brazil. Braz J Health Rev [Internet]. 2019[cited 2020 Nov 6];2(3):2228-38. Available from: http://www.brjd.com.br/index.php/BJHR/article/ view/1639/1572

11. Cecílio HP, Higarashi IH, Marcon SS. Opinião dos profissionais de saúde sobre os serviços de controle da tuberculose. Acta Paul Enferm. 2015;28(1):19-25. https://doi.org/10.1590/1982-0194201500005

12. World Health Organization (WHO). Global tuberculosis report [Internet]. Geneve: WHO; 2020 [cited 2020 Nov 6]. Available from: http://www. who.int/tb/publications/global_report/en/

13. Andrade KV, Nery JS, Araújo GS, Barreto ML, Pereira SM. Associação entre desfecho do tratamento, características sociodemográficas e benefícios sociais recebidos por indivíduos com tuberculose em Salvador, Bahia, 2014-2016. Epidemiol Serv Saúde. 2019;28(2):e201822. https://doi.org/10.5123/S1679-49742019000200004

14. Ministério da Saúde (BR). Boletim Epidemiológico Secretaria de Vigilância em Saúde. Brasil Livre da Tuberculose: evolução dos cenários epidemiológicos e operacionais da doença [Internet]. Boletim Epidemiológico. 2019 [cited 2020 Nov 6];50(9):1-18. Available from: https:// portalarquivos2.saude.gov.br/images/pdf/2019/marco/22/2019-009.pdf

15. Governo do Estado do Maranhão. Secretaria Estadual de Saúde. Conselho Nacional de Secretários de Saúde. Plano Estadual de Saúde. PES 2016-2019 [Internet]. São Luís: Governo do Maranhão; 2016 [cited 2020 Nov 6]. Available from: https://www.conass.org.bg/pdf/planosestaduais-de-saude/MA_Plano\%20de\%saude\%202016-2019.pdf

16. Ministério da Saúde (BR). Secretaria de Vigilância em Saúde. Departamento de Vigilância das Doenças Transmissíveis. Brasil Livre da Tuberculose: Plano Nacional pelo Fim da Tuberculose como Problema de Saúde Pública [Internet]. Brasília, DF: Ministério da Saúde. 2017 [cited 2020 Nov 6]. Available from: http://bvsms.saude.gov.br/bvs/publicacoes/brasil_livre_tuberculose_plano_nacional.pdf

17. Instituto Brasileiro de Geografia e Estatística (IBGE). Cidades e Estados. Imperatriz [Internet]. Brasília, DF: IBGE; 2018 [cited 2020 Nov 6]. Available from: https://www.ibge.gov.br/cidades-e-estados/ma/imperatriz.html

18. Ministério da Saúde (BR). Secretaria de Vigilância em Saúde. Departamento de Vigilância das Doenças Transmissíveis. Manual de Recomendações para o Controle da Tuberculose no Brasil [Internet]. Brasília, DF: Ministério da Saúde; 2019. 2019 [cited 2020 Nov 6]. Available from: http://bvsms.saude.gov.br/bvs/publicacoes/manual_recomendacoes_controle_tuberculose_brasil_2_ed.pdf

19. Oliveira U, Brescovit AD, Santos AJ. Delimiting areas of endemism through kernel interpolation. PLoS One. 2015;10(1):e0116673. https://doi. org/10.13710116673

20. Alves LS. Áreas de risco de mortes por tuberculose em Londrina/Paraná: uma abordagem geoepidemiológica. Ribeirão Preto: USP, 2018

21. Druck S, Carvalho MS; Câmara G, Monteiro AMV, editors. Análise espacial de dados geográficos [Internet]. Brasília (Brasil):EMBRAPA; 2004 [cited 2021 Mar 10]. Available from: http://www.dpi.inpe.br/gilberto/livro/analise/

22. Stopka TJ, Goulart MA, Meyers DJ, Hutcheson M, Barton K, Onofrey S, et al. Identifying and characterizing hepatitis C virus hotspots in Massachusetts: a spatial epidemiological approach. BMC Infectious Diseases. 2017;17(1):294. https://doi.org/10.1186/s12879-017-2400-2

23. Zheng Qi, Yang W, Wang YF. Epidemiological analysis of pulmonary tuberculosis in Heilongjiang Province China from 2008 to 2015 . Int J Mycobacteriol. 2017;6(3):2-4. https://doi.org/128.201.173.196

24. Kulldorff M, Nagarwalla N. Spatial disease clusters: detection and inference. Stat Med. 1995;14(8):799-810. https://doi.org/10.1002/ sim. 4780140809

25. Kulldorff M. An isotonic spatial scan statistic for geographical disease surveillance. J Natl Inst Public Health [Internet]. 1999 [cited 2020 Nov 6];48(2):94-101. Available from: https://www.satscan.org/papers/ku-JNIPH1999.pdf 
26. Olfatifar M, Karami M, Hosseini SM, Parvin M. Clustering of pulmonary tuberculosis in Hamadan Province, west of Iran: a population based cross sectional study (2005-2013). J Res Health Sci [Internet]. 2016 [cited 2020 Nov 6];16(3):166-9. Available from: http://jrhs.umsha.ac.ir/ index.php/JRHS/article/view/2824/pdf

27. Arroyo LH, Yamamura M, Palha PF, Ramos AC, Uchoa SA, Arcêncio RA. Identificação de áreas de risco para a transmissão da tuberculose no município de São Carlos, São Paulo, 2008 a 2013. Epidemiol Serv Saude. 2017;26(3):525-34. https://doi.org/10.5123/ S1679-49742017000300010

28. Dahlgren G, Whitehead M. Policies and strategies to promote social equity in health. Background document to WHO - Strategy paper for Europe [Internet]. Arbetsrapport/Institutet för Framtidsstudier; 2007 [cited 2020 Nov 6]. Available from: https://www.researchgate.net/ profile/Goeran_Dahlgren/publication/5095964_Policies_and_strategies_to_promote_social_equity_in_health_Background_document_ to_WHO_-_Strategy_paper_for_Europe/links/569540f808aeab58a9a4d946.pdf

29. Comissão Nacional sobre Determinantes Sociais da Saúde (CNDSS). As causas sociais das iniquidades em saúde no Brasil [Internet]. Rio de Janeiro: Fundação Oswaldo Cruz; 2008 [cited 2020 Nov 6]. Available from: http://bvsms.saude.gov.br/bvs/publicacoes/causas_sociais_ iniquidades.pdf

30. World Health Organization (WHO). Meeting report. All for equity. World conference on social determinants of health [Internet]. Rio de Janeiro:WHO; 2011 [cited 2020 Nov 6]. Available from: http://www.who.int/sdhconference/resources/Conference_Report.pdf

31. Kritski A, Draurio B, Junqueira-Kipnis AP, Moraes MO, Campos MM, Degrave WM, et al. Brazilian Response to Global End TB Strategy: the National Tuberculosis Research Agenda. Rev Soc Bras Med. 2016;49(1):1-11. https://doi.org/10.1590/S0037-86822012000500013

32. Zhao Q, Wang L, Tao T, Xu B. Impacts of the "transport subsidy initiative on poor TB patients" in Rural China: a patient-cohort based longitudinal study in Rural China. PLoS One. 2013;8(11):e82503. https://doi.org/10.1371/journal.pone.0082503

33. Tipayamongkholgul M, Podang J, Siri S. Spatial Analysis of social determinants for tuberculosis in Thailand. J Med Assoc Thai. 2013;96(12):116. https://doi.org/https://www.researchgate.net/publication/262580980 